\title{
Democracia de Assembleia e Democracia de Parlamento: uma breve história das instituições democráticas
}

MARILDE LOIOLA DE MENEZES"

\section{Resumo}

No debate sobre o imenso legado cultural da Grécia antiga, a questão da democracia é sempre evocada como ideal de participação direta dos cidadãos nas decisões coletivas, em oposição ao conceito moderno de representação política. Na busca não somente de oposições, mas de áreas comuns entre os dois conceitos, este artigo procura demonstrar que a teoria dos três poderes propugnada por Aristóteles e posteriormente retomado por Montesquieu nos conduz a um proeminente fio condutor nas relações que se estabelecem entre antigos e modernos Palavras-chave: Democracia. Participação. Representação.

\footnotetext{
* Professora do Instituto de Ciência Política Universidade de Brasília. Doutora em Sociologia pela École des Hautes Études en Sciences Sociales - Paris. Pós Doutorado em Teoria e Filosofia da História - Centre Louis-Gernet de Recherches Comparées sur les Sociétés Anciennes EHESS, Paris. (Bolsista CAPES jun 2006/jul 2007)
} 


\section{Introdução}

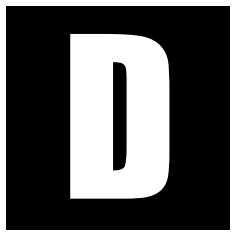

esde os gregos até nós, a ideia de que a democracia significa "governo do povo" ou "governo da maioria" tem um significado que via de regra denota um governo voltado para a distribuição mais equitativa do poder e da riqueza social. Todavia, entre a cidade-Estado e o Estado moderno, o conceito de democracia sofreu deslocamentos importantes que proporcionam grande diversidade de abordagens que ora se aproximam, ora se distanciam, de seu modelo inicial.

Uma das modificações mais significativas no diálogo entre antigos e modernos foi certamente a transferência do processo de participação direta do cidadão nos negócios públicos para um sistema centralizado de representação política. Para os antigos, a esfera pública dizia respeito ao lugar específico de tomada de decisão política por parte de seus cidadãos. No Estado moderno, a participação política é mediada por um corpo independente de políticos profissionais com legitimidade para decidir em nome dos cidadãos. Essa talvez seja a maior diferença entre a democracia antiga e a democracia moderna de nossos dias.

Ao perscrutar oposições e áreas comuns entre os dois conceitos demonstramos que a reflexão política de Montesquieu nos encaminha ao profícuo diálogo entre antigos e modernos.

\section{Os primórdios}

Ao explicar a etimologia de "maldito", Heródoto narra um dos primeiros episódios que inauguram a história política ateniense. Trata-se de um jovem aristocrata que, orgulhoso por ter vencido nos jogos olímpicos, "recruta um bando de gente de sua idade e tenta se apoderar da Acró- 
pole, mas fracassa no seu empreendimento e se refugia suplicante ao lado da estátua de Atenas" (HERÓDOTO, 1964, Livro V, p. 384). Cylon e seus seguidores se rendem sob a condição de não serem condenados à morte, mas a promessa é quebrada e os cúmplices de Cylon são todos massacrados. Posteriormente, em função do caráter sagrado da acrópole, o arconte ${ }^{1}$, responsabilizado e julgado por sacrilégio, seria condenado ao exílio, e todos os membros de sua família, os Alcmeônidas, considerados "malditos".

Esta era a lei na cité: se um membro da família cometesse um crime por homicídio ou sacrilégio, a punição recairia sobre toda a sua família e todas as gerações futuras. "Depois disso", continua Aristóteles, "os nobres e o povo entraram em conflito durante longo tempo".

Seja pelo caráter sagrado da acrópole, seja pela participação popular ou pelo conflito aberto que se instaura entre povo e aristocracia, dez anos mais tarde tais disputas provavelmente motivaram a entrada na cena política do que hoje conhecemos como "Código de Drácon"². Supostamente escrito em 621 a.C., a formulação dessas leis tinha como objetivo limitar as vinganças de morte entre famílias, prescrevendo punições para os casos de assassinato.

Aristóteles indica algumas pistas do impacto dessas primeiras iniciativas de regulamentação da vida social: na Constituição de Atenas, chega mesmo a induzir uma forma de clivagem na história política de Atenas, "antes e depois de Drácon", qualificando de "regime primitivo" as formas de organização social anteriores a Drácon (ARISTÓTELES, 1967, p. 17-22). Quanto à tradição hostil que se desenvolve a esse modesto conjunto de leis, devemos em parte a Plutarco, na medida em que coloca em dúvida a eficácia de um código "que só conhece como sanção a pena de morte" (PLUTARCO, 2001, p. 213). Mesmo assim, a lei sobre o homicídio conti-

1 O termo designa o supremo magistrado da cidade.

2 Grande parte de helenistas (Finley, Hansen, Mossé) considera improvável que Drácon tenha redigido um código de leis ou dotado Atenas de uma Constituição. 
nuou em vigor até o fim do século $V$ antes de Cristo, e uma codificação total da vida social só foi implementada bem mais tarde, por meio de Sólon.

Designado arconte, Sólon (entre 594-593 a.C.) assumiu a posição de conciliador e legislador ante os problemas econômicos que assolavam a sociedade ateniense (ARITÓTELES, 1967). Os campesinos, em função de suas dívidas progressivas, encontravam-se em situação de total dependência em relação aos proprietários senhores da terra ${ }^{3}$. Segundo o relato de Plutarco, mesmo sendo um "eupátrida" ${ }^{4}$, somente Sólon poderia formular um pacto entre ricos e pobres: "os ricos, em função das condições materiais satisfatórias de Sólon; os pobres, por suas qualidades morais" ${ }^{5}$. Assim, o lema "A igualdade não engendra a guerra", adotado por Sólon, agradava ricos e pobres: os primeiros porque julgavam que a igualdade era fundada em função de seus próprios méritos e de seus respectivos valores; os segundos porque avaliavam a igualdade como um direito de todos. (PLUTARCO, 2001, p. 209).

Uma das primeiras medidas de Sólon foi abolir dívidas e decretar também a interdição de qualquer forma de empréstimo tendo como garantia a pessoa do próprio credor. Na esfera da justiça, uma de suas primeiras medidas foi a abolição - salvo a lei sobre homicídio - das leis de Drácon. Sólon considerava que as penas fixadas por Drácon, não sendo "escritas com tinta, mas com sangue" não distinguiam quem rouba uma fruta de quem comete o sacrilégio de um assassinato (PLUTARCO, 2001,

\footnotetext{
3 Dentre eles alguns trabalhavam a terra em troca da hectémores; havia os assalariados e mais outros que ofereciam sua existência como garantia das próprias dívidas: tornavam-se escravos de Atenas ou eram vendidos no estrangeiro. Ainda existiam os que eram obrigados a vender seus filhos para escapar da crueldade dos credores.

4 Proveniente da aristocracia.

5 Referindo-se a essa passagem da vida de Sólon, Plutarco acrescenta que Phanias de Lesbos, filósofo da Escola peripatética, considerava que para salvar a cite Sólon enganava as duas partes. Em segredo, prometia aos pobres a partilha dos bens; aos ricos, a confirmação das dívidas por parte dos credores (PLUTARQUE, 2001, Vie Parallèles, p. 209).
} 
p. 212). No que concerne às magistraturas, Sólon não operou grandes mudanças, e os cargos continuaram a ser ocupados pelos ricos.

Atribui-se também a Sólon a mudança de critério na divisão do conjunto dos cidadãos atenienses em quatro classes sociais: os pentacosiomedimnos, os hippeis, os zeugitas e os tetes seriam classificados não mais a partir de seu nascimento, mas a partir de sua fortuna calculada pela produção de suas respectivas propriedades (ARISTÓTELES, 1967, p. 8). Ao modificar o critério de nascimento pelo da aquisição de fortuna na divisão do conjunto de cidadãos, Sólon inaugura a possibilidade de participação popular no processo de eleição às mais altas magistraturas. As duas primeiras classes (pentacosiomedimnos e hippeis) poderiam compor o Tribunal do Aerópago ${ }^{6}$, e a terceira classe (os zeugitas) poderia igualmente se eleger às magistraturas inferiores. Os últimos, os tetes, não eram contemplados por cargos, mas tinham acesso às assembleias.

Sólon criou o Conselho dos Quatrocentos, composto por cem membros de cada tribo, e lhes confiou a tarefa de examinar e avaliar com antecedência todos os assuntos a serem debatidos pela assembleia. Tais medidas não impediam a participação do cidadão, ao mesmo tempo em que impunham certo controle em eventuais "excessos" por parte do povo. Por outro lado, tendo dividido não só a sociedade, mas também o acesso aos cargos públicos a partir da fortuna mensurada pela propriedade da terra, não era de espantar que os "bemnascidos" ocupassem posições hegemônicas, ficando o povo com a participação restrita às Assembleias.

Esses três núcleos - o Conselho dos Aerópagos, o Conselho dos Quatrocentos e a Assembleia - co nstituíam a base de poder das reformas solonianas. A Constituição de Sólon não era obviamente um corpo sistemático de leis no sentido moderno do termo, no entanto representava uma tentativa bem sucedida de regulamentação da vida social, na qual se

6 Tribunal ateniense que na época clássica era formado pelos antigos arcontes. 
podia estabelecer determinado equilíbrio entre a ação dos proprietários de terra e a maioria campesina.

Em 507, Clístenes substitui a tradicional Constituição aristocrática por uma nova forma de Constituição democrata. As reformas no interior da velha ordem social se operam a partir de uma vertente que institui uma nova divisão geográfica e política da Ática e outra que amplia o Conselho dos Quatrocentos, que passa a ter quinhentos membros. A nova Boulè dos Quinhentos, a Assembleia e o Tribunal do Povo constituem os principais fundamentos de uma estrutura política que vai perdurar por mais 700 anos (HANSEN, 1993).

\section{Ekklésia, Boulè, Hélié}

A ekklésia era a Assembleia do Povo e nela o cidadão ateniense adulto de sexo masculino tinha direito a palavra e voto. Reunia-se com um mínimo de seis mil cidadãos, numa colina chamada Pnyx, nas proximidades da ágora. Dela estavam excluídos escravos, estrangeiros, muIheres, crianças e cidadãos privados de seus direitos políticos (atimoi). ${ }^{7}$ Caso algum representante desses segmentos fosse encontrado durante a realização de uma Assembleia, poderia ser condenado a sérias punições.

Aristóteles descreve a ekklésia como o fórum credenciado para decidir a paz e a guerra; para construção e/ou rompimentos de alianças; para a promoção de leis, bem como para aplicá-las em caso de banimentos, de confiscações ou de pena de morte. Era também através da Assembleia que os magistrados prestavam contas de suas decisões durante (ou ao término de) seus respectivos mandatos (ARISTÓTELES, 1964, Cap. X, p. 115).

A Assembleia era convocada pela Boulè dos Quinhentos e se reunia quarenta vezes por ano ou quatro vezes por pritania. Os prítanes (em

7 A perda dos direitos políticos era causada por delitos como maus-tratos aos pais, não-cumprimento dos deveres militares; dilapidação do patrimônio; prostituição etc. 
número de nove) presidiam a Boulè dos Quinhentos e a Assembleia do Povo. Eram compostos pelos cinquenta membros de uma das tribos que compunham a Boulè dos Quinhentos e que durante um décimo do ano exercia a pritania, ou seja, a Presidência da Boulè. A ordem pela qual as dez tribos da Ática se sucediam exercendo a pritania era sorteada a cada ano (ARISTÓTELES, 1967, p. 46). Além das reuniões semanais, a Ekklésia kyria era uma Assembleia maior, mais longa e se reunia uma vez por pritania.

A Constituição de Atenas, de Aristóteles, fornece-nos exemplos de variadas formas de deliberações das assembleias: decidiam com a mão elevada se os magistrados deveriam (ou não) continuar nos respectivos cargos; deliberavam sobre questões ligadas à defesa do país; faziam a leitura dos bens confiscados pelo Estado, das denúncias de alta traição e do julgamento sobre os direitos de sucessão de uma filha épiclère ${ }^{8}$.

Também cabia à Assembleia, na sua sexta prytania, incluir na ordem do dia a aplicação (ou não) do voto sobre o ostracismo, assim como sobre a aplicação (ou não) de votação contra os sykophantes ${ }^{9}$ ou contra todo aquele sobre os quais pesavam acusações de eventuais omissões em relação aos interesses do povo. Tais acusações, provenientes de atenienses ou de metecas $^{10}$, só poderiam ser realizadas em número de seis: três denúncias por categoria (ARISTÓTELES, 1967, p. 47).

Uma outra assembleia era consagrada "aos suplícios". Nesta, todo cidadão poderia colocar um "ramo de suplicante", significando que gostaria de propor uma discussão ou deliberação sobre outros assuntos (privados e públicos) que não necessariamente constassem da pauta da assembleia. Duas outras Assembleias eram consagradas a assuntos gerais, porém as leis ordenavam que em cada uma delas deveriam ser debatidas

8 A filha que herdou o patrimônio, em caso de ausência de herdeiro do sexo masculino. 9Os sykophantes eram acusadores quase profissionais. A justiça ateniense não possuía algo como o Ministério Público, que em nome da cite defendesse os interesses da coletividade. A defesa dos interesses públicos ficava ao encargo do conjunto dos cidadãos.

10 Estrangeiro autorizado a viver na cité. 
três questões relativas a coisas sagradas, três questões relativas a arautos ou embaixadores e mais três questões profanas.

Quanto à pauta das assembleias, não se tinha direito de votar nenhuma questão sem o parecer da Boulè. A pauta eram examinada com antecedência pela Boulè dos Quinhentos, e era essa instância que decidia a ordem do dia da ekklésia. Da mesma forma que a probouleuma era um projeto elaborado pela Boulè e submetido à votação da ekklésia. Para ser ratificado, a Assembleia precisava do quórum mínimo de seis mil cidadãos votando com seus jetons (psèphoi) com a mão para o alto. Os jetons eram distribuídos aos participantes da Assembleia no momento de sua chegada. Como ninguém poderia ter dois psèphoi à mão, isso garantia a contagem correta dos votos (HANSEN, 1993, p. 160).

As eleições dos estrategos, dos hipparques e dos outros funcionários militares era também feita pela Assembleia. Os estrategos eram os generais comandantes do exército em terra e mar, investidos de plenos poderes nos campos de batalha. Em Atenas esse colegiado trabalhava junto com a Boulè dos Quinhentos e presidiam a Hellié, o Tribunal do Povo. Constituíam um colegiado de dez cidadãos eleitos por um ano e renovação indefinida. Hipparques era a denominação que se dava à lista de cavaleiros eleitos na Assembleia ${ }^{11}$. A escolha dos estrategos e dos hipparques ocorria a partir da "primeira após a sexta prytania se os presságios fossem favoráveis" (ARISTÓTELES, 1967, p. 48). Essa operação exigia igualmente o voto preliminar da Boulè.

Constituindo-se na principal instância de participação política, a ekklèsia ocupava lugar e excelência como principal base política das instituições democráticas atenienses. É a instância direta de participação do cidadão. Entretanto, apesar de tal participação ser aberta a todos, Aristóteles chama a atenção para o fato de que as assembleias eram dominadas

11 Segundo o testemunho de Tucídides, nas vésperas da guerra do Peloponeso existiam mil hipparques (Hérodote - Thucydides. Oeuvres completes. Paris: Edição Bibliothèque Pléiade, 1964). 
pelos demagogos, que com sua retórica conduziam o povo a aprofundar a clivagem entre ricos e pobres e ao mesmo tempo o induzia a confiscar recursos do Estado por meio da distribuição irresponsável do dinheiro público com os "pequenos espíritos"12. Esses oradores (rhètorés) tinham bastante domínio sobre as assembleias. Mesmo que todo cidadão, em tese, tivesse direito à palavra, eram os demagogos verdadeiros profissionais da política, que se sucediam na tribuna.

Para o filósofo, "deliberamos melhor quando todos deliberam em comum: o povo com os nobres e os nobres com o povo" (ARISTÓTELES, 1964, cap. X, p. 115). Isso significa que os membros da Assembleia deveriam ser escolhidos de forma igual, por eleição ou por sorteio, a partir das diversas classes da cidade-Estado. Como os cidadãos do povo constituíam a maioria, os sorteios ou os pagamentos dos salários deveriam ser feitos tendo como base o mesmo número dos nobres presentes na Assembleia. Por esse artifício, tanto o povo como os nobres teriam asseguradas suas participações, de forma equilibrada, nas assembleias do povo.

A caracterização do meio termo aristotélico entrava assim em contradição com a noção democrática de governo do povo, governo de maioria. Para os filósofos do século IV, a democracia se caracteriza pela participação do povo em todas as matérias e em todos os assuntos. O regime democrático teria assim como princípio básico a participação popular em todas as instâncias da cidade-Estado. A possibilidade de representação justa e equilibrada dos dois segmentos sociais - povo e aristocracia - se chocava com o princípio da "isonomia" democrática. ${ }^{13}$

12 Aristóteles se refere a misthoforia, lei de Péricles que obriga a cite a um pagamento aos pobres que comparecem à Assembleia. Para Aristóteles, quando o Estado não tem muitos recursos é preciso só raramente convocar a ekklésia (ARISTÓTELES, La Politique, op. cit cap. XVIII, p. 212-213).

13 A "isonomia" é o princípio básico da igualdade política, o que não significa igualdade diante da lei dos modernos, embora fosse a igualdade de todos cidadãos para exercer seus direitos políticos. 
A Constituição de Atenas se refere a uma outra instituição central na compreensão da democracia ateniense: a Boulè dos Quinhentos (ARISTÓTELES, 1967, p. 48). Este Conselho foi instituído por Clístenes em 507 a.C. e tinha como base organizacional uma nova divisão política e militar da Ática: dez tribos, trinta circunscrições e 139 municipalidades (dèmes). Os membros do Conselho, os quinhentos bouleutes, eram escolhidos por sorteio: cinquenta representantes do conjunto de cidadãos de cada tribo (ARISTÓTELES, 1967, p. 46). Para ser bouleute era necessário ter pelo menos trinta anos de idade e ter passado com sucesso pela dokimasie, isto é, um exame prévio à magistratura. ${ }^{14}$

Cada tribo exercia uma prytania fixada nesta ordem: "as quatro primeiras durante 36 dias, as seis últimas durante 35 dias. Os cinquenta membros de cada tribo deveriam servir no comitê executivo do Conselho por um décimo do ano. O Conselho era guiado pelo ano bouleutique, cuja duração era de dez meses (prytaneiai) e não de doze meses, como no ano civil atual. A ordem de sucessão das tribos, a prytania, era igualmente sorteada ao final de cada pritania.

Os prytanes faziam suas refeições em comum na rotonde (tholos) recebendo do Estado uma recompensa em dinheiro. Eram responsáveis pela convocação da Boulè e da Assembleia do Povo. O Conselho se reunia todos os dias, à exceção dos feriados, e a Assembleia quatro vezes por prytania. Os prytanes se responsabilizavam por todas as tarefas do Conselho, como também faziam uma síntese de todos os assuntos em pauta a serem debatidos pela Assembleia do Povo. Eram igualmente os prytanes que faziam a seleção do que deveria ser tratado na ordem do dia das Assembleias.

Ao Conselho cabia julgar a ação dos magistrados, principalmente os responsáveis pela manipulação de fundos. Aqui também o julgamen-

14 Aristóteles nos dá uma indicação do que seriam essas questões: Quem é o teu pai e a qual dème ele pertence? Quem é o pai de teu pai? Quem é a tua mãe? Quem é o pai da tua mãe e a qual dème ele pertence? (Constitution d'Athènes,op.cit., p. 46). 
to não era definitivo, havendo a possibilidade de apelar para uma outra instância, o Tribunal do Povo (Hélié), que em Atenas julgava processos civis e criminais, ações de ordem privada e de ordem pública. Além disso, examinava as questões ligadas a denúncias de magistrados, bem como julgava os processos políticos. Algumas vezes anulava os decretos que haviam sido votados pela Assembleia e as leis votadas pelos nomothètes ${ }^{15}$.

Poderia fazer parte do Tribunal do Povo (Hélié) todo cidadão com mais de trinta anos, à condição de que não fosse devedor do tesouro público ou estivesse privado de seus direitos políticos. Qualquer cidadão que tentasse assumir o júri sem preencher esses pré-requisitos e fosse delatado e reconhecido como culpado seria condenado e mantido em prisão até o dia em que quitasse a dívida que lhe causara a delação e mais uma multa imposta pelo Tribunal.

A cada ano, um corpo de seis mil pessoas era sorteado entre os cidadãos voluntários de mais de trinta anos. Uma vez sorteados prestavam o sermão (héliastique) no qual se engajavam a votar de acordo com a lei os decretos da Assembleia e do Conselho; prometiam também que iriam escutar imparcialmente a defesa e a acusação. A partir desse momento os cidadãos formavam um corpo de héliastes que seria sorteado para compor um júri que normalmente variava entre duzentos e quinhentos cidadãos, podendo chegar a 1.500, dependendo do porte da acusação. Em geral, as questões de ordem privada envolviam cerca de 201 a 401 cidadãos. As demais, de ordem pública, 501 cidadãos.

São essas três instituições que originadas no século $\vee$ vão encarnar os principais fundamentos do pensamento político moderno. Nesse diálogo constante com o legado dos antigos, cremos ser em Montesquieu que podemos encontrar o fio condutor dessas "zonas comuns" que se

15 Comissão legislativa constituída por cidadãos (cem, por exemplo) sorteados por meio de um painel de seis mil jurados, para legislar durante uma jornada. 
estabelecem entre as instituições políticas dos antigos e dos modernos. Mesmo se no Esprit des Lois o autor se demonstra fascinado pela história de Roma, não se pode negar a influência da Grécia antiga na obra de Montesquieu sobretudo na figura do grande legislador Sólon e na herança do pensamento filosófico de Platão e Aristóteles.

\section{Poder Legislativo, Poder Executivo e Poder Judiciário}

Analisando a Constituição Inglesa no famoso Livro IX do Esprit des Lois, Montesquieu reflete sobre a relação entre as leis fiadoras da liberdade política e suas respectivas constituições. A ideia geral do autor era analisar os mais variados significados da palavra liberdade, assim como a suposta relação entre liberdade e democracia. Em outras palavras, se o objetivo da sociedade é a liberdade de seus membros, que tipo de governo poderá garantir tal liberdade? Montesquieu se empenha em primeiro lugar em fazer a diferença entre a liberdade filosófica, ligada à questão da vontade do agente, e a liberdade política, ligada ao cumprimento das leis. Um povo é livre na medida em que suas leis estão em consonância com seus costumes e tendências. Em um estado guiado pelas leis, a "liberdade consiste em fazer não aquilo que queremos fazer, mas aquilo que devemos fazer" (MONTESQUIEU, 1951, Livro XI, cap. III, p. 395).

Dessa forma, a liberdade política deriva não da vontade individual, mas do exercício do cumprimento da lei. Entretanto, sendo os homens "[...] seres particulares inteligentes, podem ter leis que eles fizeram, mas que também não fizeram" (MONTESQUIEU, 1951, Livro I, cap. I, p. 232). As primeiras são as leis positivas, que podem ser criadas, mudadas e suprimidas pelas autoridades estabelecidas. As segundas são as leis absolutas, universais e eternas. Sendo as leis eternas naturalmente justas, nenhuma autoridade constituída poderá mudá-las ou aboli-las. Na medida em que nenhuma lei positiva pode ofender o ideal de justiça divina, pode-se pen- 
sar numa justiça que seja universal e ao mesmo tempo derivada da razão humana. Nessa hipótese a lei se constitui na própria razão humana, no sentido de que "ela governa todos os povos da terra; as leis políticas e civis de cada nação são casos particulares onde se aplica essa razão humana" (MONTESQUIEU, 1951, Livro I, cap. III, p. 237). Dessa forma, Montesquieu recusa a ideia de que o homem possa de forma autônoma e arbitrária constituir suas próprias leis. Estas devem resultar de uma relação ontológica entre o mundo natural universal e o mundo singular dos homens.

De outro modo, a liberdade de um povo, de um Estado, depende também da justiça de suas leis. Entretanto, para que estas leis sejam realmente justas é preciso que consigam obstar as ambições humanas. A ideia de justiça de Montesquieu está diretamente relacionada à sua concepção de natureza humana: qualquer pessoa que detenha um mínimo de poder tentará excedê-lo. Portanto, todo poder de um homem ou de muitos sobre os outros conduz inexoravelmente a um aumento de poder. Todo aquele investido de poder poderá ficar vulnerável a cometer excessos. Por esse motivo, nem a democracia nem a aristocracia se constituem, de forma espontânea, em Estados livres. Só se encontra liberdade política nos governos moderados. Somente estando os poderes contrabalançados, separados, equilibrados por um corpo intermediário, é que se pode limitar a inclinação natural ao abuso de poder.

Para que se possa preservar o poder de todos os excessos é preciso que o "poder detenha o poder" (MONTESQUIEU, 1951, Livro XI, cap. IV, p. 395). Sendo o homem "limitado por sua própria natureza" (MONTESQUIEU, 1951, Livro I, cap. I, p. 233), encontra-se sempre sujeito a erros e a imprevisibilidades. Como ser inteligente, consegue "constantemente violar as leis estabelecidas por Deus e aquelas que estabelece para si próprio" (MONTESQUIEU, 1951, Livro I, cap. I, p. 234). Para não se entregar a "mil paixões" o homem deve ser constantemente "reconduzi- 
do". Sujeito a tanta vulnerabilidade, coube aos filósofos adverti-los com leis morais, éticas. Para viver em sociedade, aos legisladores igualmente compete advertirem-nos com leis políticas e civis. As liberdades moral e política só poderão ser atingidas com a prática da moderação. Embora o Esprit des Lois não se proponha a ser uma obra de cunho moral, nada impede que o bem moral e o bem político possam se unir em nome da paz e do bem coletivos.

É com essa expectativa que se refere ao Estado como detendo três tipos de poderes: o legislativo, o executivo e o judiciário: "Não há liberdade se o poder de julgar não for separado do poder legislativo e do executivo" (MONTESQUIEU, 1951, Livro XI, cap. IV, p. 396). A ideia de Montesquieu era impedir que um mesmo homem exercesse os três poderes: o de fazer as leis, o de executar as resoluções públicas e o de julgar os crimes ou as contendas entre particulares. A autoridade política deve ser exercida por mecanismos institucionais que assegurem o funcionamento equilibrado entre os três poderes. Os mecanismos incluem uma Constituição moderada, na qual a colaboração entre os três poderes permita cooperação e complementaridade funcional articuladas, que os obrigarão a "agir em concerto" (MONTESQUIEU, 1951, Livro XI, cap. VI, p. 405).

Assim, não fazendo parte do poder legislativo, o poder executivo não poderá entrar nas disputas que se travam na formulação e na aprovação das leis. Por sua vez, estando o poder executivo isento da redação das leis, detém, dessa forma, o direito de "impedimento", isto é, "o direito de anular uma resolução tomada por outro" (MONTESQUIEU, 1951, Livro XI, cap. VI, p. 401), o direito de veto. Considerando que a sociedade tem necessidade de leis que possam regulamentar a conduta de cada um em particular e da sociedade em geral, as leis regulamentam melhor "aquilo que devemos aos outros" do que "tudo que se deve a si mesmo"(MONTESQUIEU, 1951, Livro VII, cap. X, p. 343). 
Recusando a via aberta por Hobbes, em que o Leviatan se constitui no único legislador em todos os domínios da sociedade, para Montesquieu as leis positivas não devem sua existência nem sua justificação ao domínio restrito dos homens. Dada a precariedade do homem - sempre sujeito à ignorância e ao erro - as leis positivas devem ter como modelo as leis naturais, únicas a atingirem a infinita perfeição divina.

Para atingir essa justiça universal, Montesquieu afirma que ao contrário do poder executivo, que "deve ficar nas mãos de um monarca, uma vez que precisando tomar decisões rápidas será mais bem administrado por um do que por muitos" (MONTESQUIEU, 1951, Livro XI, cap. VI, p. 401-402), o poder legislativo ficará mais bem ordenado se administrado por muitos do que somente por um. A ideia de um executivo solitário e um legislativo coletivo reflete bem o âmago das preocupações do pensamento político montesquiano: a delimitação do poder e a consolidação de mecanismos institucionais que possam oferecer estabilidade ao sistema político.

Montesquieu vê nos mecanismos institucionais uma garantia face à capacidade do homem em "violar sem cessar as leis que Deus estabeleceu e mudar as que ele mesmo estabeleceu" (MONTESQUIEU, 1951, Livro I, cap. I, p. 234). A consolidação de instituições políticas pautadas na justiça e na impessoalidade constituiriam uma proteção confiável para que o homem não ficasse "sujeito a mil paixões", esquecendo a si mesmo e ao seu próprio criador: é por essa razão que "os filósofos devem advertilos com suas leis morais, e os legisladores através de suas leis políticas e civis" (MONTESQUIEU, 1951, Livro I, cap. I, p. 234).

Aos legisladores compete aproximarem a "terra do céu", transformando-se no segundo vetor que compõe o equilíbrio institucional: o poder legislativo, a ser composto de duas câmaras: uma câmara alta e outra câmara baixa. 
Para Montesquieu, em todos Estados livres cabe ao povo o poder de se governar e de fazer as leis. Sendo impossível nos grandes Estados e "problemático" nos pequenos, é preciso que tenham seus representantes, porque um dos grandes "embaraços" causados pela democracia é a limitação do povo quanto a suas respectivas capacidades no exercício dos cargos públicos. A grande vantagem dos representantes é que seriam capazes de discutir os negócios do Estado e ao mesmo tempo superar um dos grandes vícios das democracias antigas, ou seja, o excesso de poder proveniente do povo.

Confiado a duas câmaras, o poder legislativo teria esta configuração: uma câmara alta, composta de um corpo de nobres; e uma câmara baixa, composta por um corpo a ser escolhido para representar o povo. O corpo de nobres deveria ser hereditário pela sua própria natureza, enquanto o povo deveria ter o direito de escolher seus representantes. As duas câmaras teriam suas Assembleias com suas respectivas deliberações, de acordo com seus interesses e suas distintas posições. Tendo em vista que o equilíbrio deve também prevalecer no interior dessas duas câmaras, a parte do poder legislativo composta pelos nobres seria mais indicada para cumprir essa função. Sendo o povo conduzido por suas paixões, os nobres assumiriam um poder moderador. Como o poder hereditário pode ser eventualmente potencializado e se transformar num poder autoritário, vulnerável a ponto de seguir seus próprios interesses e a esquecer os interesses do povo, esse poder deverá sempre deter a faculdade de "impedir", mas nunca a faculdade de "estatuir". Montesquieu distingue a faculdade de "impedir" como sendo o direito de tornar nula uma resolução tomada por outra pessoa, enquanto que a faculdade de "estatuir" é o direito de conceder por si mesmo ou de corrigir aquilo que é concedido por outro. Dessa forma, cabe ao corpo representativo impedir abusos e não conceder direitos. 
Quanto ao poder judiciário, Montesquieu o considera um "poder menor"16: "Os juízes da nação representam apenas a 'boca' que pronuncia as palavras da lei; seres humanos que não podem moderar nem a força nem o rigor da lei" (MONTESQUIEU, 1951, Livro XI, cap. V, p. 404). Sendo prerrogativa do legislativo operar qualquer mudança nas leis, ao judiciário compete apenas a tarefa de a elas se submeter. Por outro lado, o poder de julgar não deve ser dado a um corpo permanente, mas exercido por pessoas sorteadas do conjunto do povo, em certas épocas do ano, de acordo com a lei, para formar um tribunal cuja duração deve ser estabelecida de acordo com as necessidades de cada caso: “Dessa forma, o poder de julgar - um dos poderes mais terríveis entre os homens - não sendo vinculado nem a um certo estado nem a uma certa profissão, torna-se, de certa forma, um poder invisível e nulo" (MONTESQUIEU, 1951, Livro XI, cap. V, p. 388).

Montesquieu entende por poder "invisível e nulo" o fato de se tratar de um corpo que apesar de não congregar os juízes de forma permanente e duradoura se legitima enquanto instância capaz de garantir a justiça ao conjunto da coletividade. E por que tal distinção? Para ele, os outros dois poderes - executivo e legislativo - podem ter como agentes um corpo ou um só representante permanente, uma vez que não exercem o poder diretamente sob um particular: sendo o poder legislativo "representante" da vontade geral do Estado, e o poder executivo a "execução" dessa vontade geral, estes poderiam agir com isenção e distância. Quanto ao poder judiciário, a única forma de transformá-lo em poder neutro, não aderente a nenhuma das partes integrantes do conflito, é quando seus integrantes são escolhidos de forma imparcial. Entende-se dessa forma a razão pela qual Montesquieu considera o judiciário como um poder menor, na justa medida em que ele se dirige ao particular e não ao geral, ao universal.

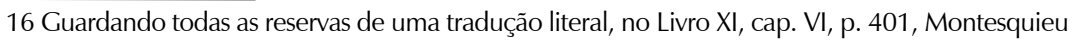
afirma que: "Dos três poderes que nós falamos, o de julgar é, de certa maneira, nulo (nulle)". 
Transformando o judiciário em um corpo volátil, Montesquieu dá mostras de sua inquietação em relação a um corpo que por sua própria natureza poderá julgar a conduta individual de todo cidadão da coletividade. Como garantir a imparcialidade de um poder que julga os membros da comunidade? Enquanto nos demais poderes a subjetividade é continuamente protegida pelo apelo à sociedade e ao bem-comum, o que fazer de um poder que exerce funções "invisíveis", quase divinas? Tais inquietações são contornadas por Montesquieu através de duas proposições complementares. A primeira, de ordem subjetiva, procura assegurar a adoção de leis precisas que possam evitar "a opinião particular do juiz" (MONTESQUIEU, 1951, Livro XI, cap. VI, p. 399). A segunda, de ordem objetiva, assegura o direito de que em casos extremos, de grandes acusações, o próprio infrator possa escolher aquele que lhe irá julgar. Ambas as propostas buscam a imparcialidade e a neutralidade como forma de contornar um dos poderes mais problemáticos das democracias modernas: o sistema judiciário.

\section{Democracia de Assembleia e Democracia de Parlamento}

A análise das três principais instituições políticas atenienses indica que a participação direta nas decisões coletivas constitui a base da democracia na Grécia antiga. Tendo como princípio básico o exercício do poder pelo povo (dêmos), a democracia antiga se opõe à democracia dos modernos, cujo único poder se resume à escolha daquele que vai decidir em nome do povo. Deste modo, o estudo sobre o legado cultural de Atenas parece reforçar a oposição clássica entre a chamada democracia participativa e a democracia representativa. A partir dessa ótica, a tão propalada crise da democracia se confunde com a crise do sistema de representação política.

Como consequência da falta de credibilidade do atual sistema, apontam-se duas grandes mazelas: a apatia política e a corrupção. 
A apatia pode ser a consequência natural da falta de confiança nos políticos e em suas respectivas capacidades de defender os interesses da coletividade. Estando em crise o sistema político, os eleitores não se sentem estimulados a participar da vida pública e dos negócios do Estado. Quanto aos políticos, suas ações ficam condicionadas aos interesses de seus partidos e às estratégias pessoais que lhes possam garantir vitória no próximo pleito. A progressiva autonomia da classe política em relação ao conjunto da coletividade pode ser a consequência natural do processo.

Quanto à corrupção, passa a ser igualmente considerada consequência natural do sistema de representação política, considerado lugar próprio para os descalabros do funcionamento dos governos e das instituições. Os políticos vêm a ser considerados como "suspeitos" face ao decoro parlamentar e à distribuição equitativa dos recursos públicos. Na consciência difusa da sociedade, os representantes subordinam os interesses públicos aos interesses individuais, ao mesmo tempo em que não operacionalizam a separação entre o público e o privado.

Nestes termos aumenta o fosso entre antigos e modernos. Sendo assegurada aos povos antigos a participação direta nos negócios públicos, a tensão entre governantes e governados torna-se constitutiva das democracias representativas. A ideia subjacente a esse tipo de formulação é a certeza de que o povo estaria naturalmente credenciado a escolher alternativas mais justas para a coletividade, enquanto as escolhas dos representantes estariam pautadas pelos interesses pessoais e pelo desejo único de reeleição.

Opor a democracia participativa como expressão de um consenso forjado a partir dos interesses coletivos e a democracia representativa como expressão dos interesses individuais é reduzir a democracia a um consenso que (embora desejado) dificilmente se realiza. Sendo a democracia não só o modelo de um regime político, mas também a expressão de uma experiência histórica, antigos e modernos sabem que somente através das tiranias 
ou de monarquias absolutas é possível "eliminar" a tensão entre governantes e governados. A própria Assembleia do Povo era constantemente palco de cisões e dissensos. O embate clássico entre filósofos e sofistas é o exemplo mais expressivo que desautoriza qualquer ideia de convivência harmônica entre os cidadãos e o poder, na Grécia antiga.

Apesar de se constituir numa importante fonte de reflexão, a alternativa teórica estritamente baseada na oposição entre democracia participativa e democracia representativa nos parece estéril. Opostamente, se incorporarmos áreas comuns às tradicionais oposições clássicas entre um e outro modelo podemos constatar que em ambos os "regimes de historicidades"17 a base da democracia e de toda decisão feita por maioria é atravessada de tensões, conflitos e muitas vezes de fortes cisões entre governantes e governados. O povo, tal como qualquer outra classe social, não se comporta de forma homogênea, e no seu interior guarda cisões, dissensos incontornáveis. Logo, quer na ekklésia, quer no parlamento, a tensão entre governantes e governados não representa uma fratura no regime político. Ao contrário, é constitutiva do regime democrático.

Uma outra área comum a ser destacada no estudo dos antigos e dos modernos se refere à questão da busca de equilíbrio entre os poderes constitucionais e o cidadão. Sem querer forçar uma continuidade entre a Boulè dos Quinhentos, a Assembleia, o Tribunal do Povo e os Três Poderes Constitucionais, podemos indicar que as preocupações modernas em estabelecer equilíbrio entre os poderes do povo e de seus respectivos representantes certamente não eram totalmente ignoradas pelo modelo ateniense.

Em Montesquieu, a autoridade política deveria ser exercida por mecanismos institucionais que pudessem assegurar o funcionamento equilibrado entre os poderes, permitindo que fossem eles "obrigados a agir em

17 Esta expressão é usada por François Hartog, quando se refere à relação que cada sociedade em particular estabelece com o passado, o presente e o futuro. Essa multiplicidade do tempo é definida pelo autor como régimes d'historicité (HARTOG, François. Régimes D'Historicité: présentisme et expériences du temps. Paris: Seuil, 2003). 
concerto" (MONTESQUIEU, Livro XI, cap. VI, p. 405). Os dados históricos demonstram que os eleitos da Boulè dos Quinhentos eram responsáveis pela pauta da Assembleia e pela execução de suas respectivas deliberações. Qualquer proposição proveniente do Conselho considerada ofensiva às leis da cité poderia ser levada para o julgamento do Tribunal do Povo ${ }^{18}$. A descrição dessas atribuições sugere que a Boulè dos Quinhentos e o Tribunal do Povo funcionavam como um contrapoder da Assembleia, da mesma forma que a análise indica também a existência de cooperação e vigilância mútuas entre a Assembleia do Povo, a Boulè dos Quinhentos e o Tribunal do Povo.

Reforçando essa pista analítica, se recorrermos aos filósofos do século IV, a filiação entre antigos e modernos torna-se mais clara. Na Apologia (de Platão), Sócrates se refere às três principais instituições da cité: a Ekklésia, a Boulè e a Heliéia (PLATÃO, 1966, Tomo I, 25a/25b). No capítulo X da Política, Aristóteles se refere igualmente a essa estrutura política como constituída por três poderes essenciais a toda forma de governo: um "poder deliberativo" que se ocupa de todos os negócios do Estado; um "poder executivo" composto pelas magistraturas; e um terceiro poder constituído pelos magistrados, o "poder judiciário" (ARISTÓTELES, 1964, cap. X, p. 115).

Um terceiro aspecto ou uma terceira área comum a ressaltar estaria circunscrito no próprio conceito de representação: como o povo em Assembleia não exercia todas as funções governamentais, a representação não era totalmente desconhecida na Grécia antiga. Certas tarefas - de ordem do executivo em particular - eram delegadas aos magistrados. Atenas possuía aproximadamente setecentos postos para os magistrados, sendo seiscentos deles sorteados e o restante escolhido por eleições. ${ }^{19} \mathrm{~A}$

18 Hansen esclarece, inclusive, que mais da metade dos decretos votados pela Assembleia sofriam retificações da parte da Boulè dos Quinhentos (La democratie athenienne. À l'époque de Démosthène, op.cit., p. 138-140).

19 Mogens Hansen, na obra La democratie athenienne. À l'époque de Démosthène op. cit, realiza uma das mais arrojadas pesquisas sobre o desenho organizacional das instituições atenienses. 
diferença entre um e outro regime histórico era que, no caso dos antigos, todos os magistrados estavam sob o controle da Assembleia.

Os atenienses reservavam a designação por eleição às magistraturas que eram consideradas vitais: os generais (estrategos), os altos funcionários militares e os das finanças públicas. Era através de cargos eletivos que se encontravam as maiores personalidades da cidade-Estado. Os magistrados eleitos poderiam ser reeleitos indefinidamente ${ }^{20}$.

Sendo a designação dos governantes realizada por meio de eleições em intervalos regulares, um dos princípios básicos do regime representativo, podemos admitir que o conceito de representação não era completamente desconhecido pelos atenienses. Aristóteles, na Política, parece confirmar nossa hipótese: "[...] são consideradas como democratas as magistraturas atribuídas pela sorte, e como oligárquicas as que são atribuídas por eleição" (ARISTÓTELES, 1964, p. 105). Seguindo Aristóteles, a grande oposição operada entre a democracia antiga e a democracia moderna, ou seja, o fiel da balança que opera a separação entre uma e outra seria o uso das eleições em detrimento do sorteio. E por que o sorteio se constitui no principal fundamento do regime democrático? Porque obedece a dois princípios constitutivos da democracia ateniense: o princípio da "isonomia" e o princípio da "isegoria".

A "isonomia" é o princípio da igualdade política, isto é, igualdade perante a lei e direitos iguais a todos os cidadãos para o exercício de seus direitos políticos. O segundo princípio, a "isegoria", fundamenta-se na igualdade de condição em relação ao uso da palavra. Isto é, o direito igual de cada cidadão de fazer proposições na Assembleia.

Quanto às eleições, princípio básico da democracia representativa, a escolha dos cidadãos se dá baseada no princípio da competência, isto é, da certeza de que somente os melhores, os notáveis, os aristos, os bemnascidos, poderiam conduzir os negócios do Estado. Nunca o regime

$20 \mathrm{O}$ mais famoso general do século $\mathrm{V}$, Péricles, foi eleito estratego entre 20 a 22 vezes seguidas, e Phocion ficou no posto durante 45 anos (Plutarco. Vie Paralèlles). 
representativo utilizou o sorteio como forma de escolha de seus representantes. Dessa forma, para nós contemporâneos, parece curioso ou até insólito pensarmos no uso do sorteio como forma legítima de participação política. Enquanto a oposição participação versus representação forjou uma base rica de discussões, de debates e "querelas", poucas são as referências analíticas que fazem menção às relações que envolvem o sorteio e a eleição entre antigos e modernos. E por quê?

Referindo-se às abordagens pautadas na oposição entre antigos e modernos, François Hartog sugere que subjacente a todas essas grandes querelas pode-se encontrar uma construção social sobre o presente. Assim, a clássica querela animada por Benjamin Constant - Liberté des Anciens comparée à celle des modernes (CONSTANT, 1997) - tinha como interesse principal formular uma resposta que pudesse substituir os valores herdados da Revolução por uma visão mais liberal da sociedade.

Em Constant a liberdade moderna é a liberdade civil ou individual. A liberdade antiga era a participação coletiva dos cidadãos no exercício da soberania. Sob o pretexto de uma recusa a uma volta inócua ao passado, "Constant se reserva o direito de omitir que sua reflexão concerne muito mais ao presente do que ao passado da França". Seu adversário principal seria Rousseau, não os antigos ${ }^{21}$. Para Hartog, "não é o presente, mas é o passado que atravessa essa ficção teórica." (HARTOG, 2005a).

Depois de sublinhar a ligação existente entre a liberdade de uns e a escravidão de outros, Rousseau se refere à soberania como o exercício pleno da "vontade geral": sendo "o soberano um ser coletivo, só pode ser representado por ele mesmo: o poder pode muito bem ser transmitido; mas a vontade, não" (ROUSSEAU, 1962). A ideia de representação rousseauniana contribuiria não para a liberdade, mas para a escravização do cidadão moderno. Para Constant, longe de ser sinal de servilismo, a representação significaria a libertação do indivíduo para que este não se

21 Hartog se refere à clássica querela Liberté des Anciens et Liberté des Modernes. 
tornasse escravo da vida pública. Assim, os antigos seriam livres e escravos. Quanto aos modernos, seriam livres e representados.

Essa foi uma das proeminentes querelas que deram origem a inúmeras clivagens entre antigos e modernos. Dentre elas a clássica discussão entre participação e representação ${ }^{22}$. Enquanto invenção dos antigos, a participação só poderia ser utilizada pelos gregos, uma vez que seria incompatível com as dimensões do Estado moderno. Tal impossibilidade "técnica" levou os antigos a ignorarem a representação, que seria uma descoberta dos modernos. Quanto ao sorteio, mesmo não sendo "incompatível" com as dimensões do Estado moderno, foi praticamente banido da prática política e pouco desenvolvido no campo da reflexão filosófica ${ }^{23}$.

É evidente que a "ficção teórica" a que se refere Hartog está no fato de que nem a representação é uma invenção do Estado moderno, tampouco a participação é privilégio da cidade-Estado. A inversão de "tipos ideais" em experiências históricas submerge os antigos num patamar "sagrado", cujo valor arqueológico é apreciado por diletantes portadores de uma singular curiosidade intelectual. À parte o valor catártico da experiência, resta-nos o saudosismo de um passado idealizado traído pelos atributos da modernidade. Sendo os antigos o "ideal de perfeição", e os modernos os "profanos do templo", seria o caso de nos perguntarmos: por que ainda estudamos os gregos?

Longe de nos lançarmos a uma nova querela - Sorteio dos antigos e Eleição dos modernos - este artigo se propõe a uma linha de reflexão em que oposições e áreas comuns entre antigos e modernos possam se constituir em importantes fontes de análise e debate no contexto das democracias contemporâneas.

22 Nos anos sessenta Finley escreveu uma interessante análise sobre a democracia dos antigos e a dos modernos (Démocratie antique et démocratie moderne. Paris: Petite Biblithèque Payort, 1976).

23 No domínio da filosofia política podemos destacar autores como Finley, Hansen, Lenoir, Manin, que sob ângulos diferentes insistem nesse debate. 


\section{Direct Democracy and Parliamentary Democracy: a brief history of the democratic institutions}

\section{Abstract}

In the debate on the immense cultural legacy of ancient Greece, the issue of democracy is always mentioned as an example of the direct participation of citizens in collective decisions, as opposed to the modern concept of political representation. In the search not only for differences but also for similarities between the two concepts, this article intends to demonstrate that the theory of the separation of powers, advocated by Aristotle, and later Montesquieu, leads to a prominent connection between ancient and modern democracy.

Keywords: Democracy. Participation. Representation.

\section{Referências}

ARISTOTELES. A Constituição de Atenas. São Paulo: Editora Hucitec, 1995.

. La Politique. Paris: Les Belles Lettres, 2002.

CONSTANT, Benjamin. Écrits politiques. Paris: Éditions Gallimard, 1997.

FINLEY, Moses. Les premiers temps de la Grèce: l'âge de bronze et l'époque archaïque. Paris: François Maspero, 1973. Payot, 1976.

. Démocratie antique et démocratie moderne. Paris: Petite Bibliothèque

HANSEN, Mogens $\mathrm{H}$. La democratie athenienne à l'époque de Démosthène. Paris: Belle Lettres, 1993.

. Pólis et Cité-État. Um concept antique et son équivalent moderne. Paris: Les Belles Lettres, 2004.

HARTOG, François. Anciens, Modernes, Sauvages. Paris: Galaade Editions, 2005a.

. Évidence de I' histoire. Ce que voient les historiens. Paris: Editions de $\overline{I^{\prime} E ́ c o l e}$ des Hautes Études en Sciences Sociales, 2005b.

. Os Antigos, o Passado e o Presente. Brasília: Editora UnB, 2003.

. Régimes D'Historicité. Paris: Seuil, 2003. 
HÉRODOTE-THUCYDIDE. Oeuvres complète. Paris: Éditions Gallimard, 1964. LENOIR, Norbert. La démocratie et son histoire. Paris: PUF, 2006.

MANIN, Bernard. Principes du Gouvernement Représentatif. Paris: CalmannLévy, 1995.

MONTESQUIEU. Oeuvres complètes. Paris: Éditions Gallimard, 1951.

MOSSÉ, Claude. Les Grecs inventent la politique. Bruxelles: Editions Complexe, 2005.

. Les institutions politiques grecques. Paris: Armind Colin, 1968.

PLATON. Oeuvres Completes. In: Apologie de Sócrates. Paris: Les Belles Lettres, 1966. Tome 1, 25a/25b.

PLUTARQUE. Vies parallèles. Paris: Gallimard, 2001.

ROUSSEAU, Jean-Jacques. Le Contrat Social. Paris: Librairie Armand Colin, 1962.

Recebido: 02/10/2007

Aceite final: 02/04/2008 